\title{
En sang til (livs)motet - en undring omkring fenomenet livsmot
}

\author{
Rolf Thorsen
}

Rolf Thorsen, førsteamanuensis, Institutt for helse og omsorgsfag, UiT: Norges Arktiske Universitet - Harstad, rolf.thorsen@uit.no

\begin{abstract}
Reflections on life courage

This essay addresses various aspects of the phenomenon of "life courage". The approach is phenomenological and draws on a Danish tradition of life philosophy. The aim is not to find definitions, but to approach the topic cautiously to reveal new aspects of the phenomenon. The text is an outer and inner journey through experience, art, literature and poetry. This journey starts by dwelling on the apparent absence of courage for life in situations of extreme darkness. Later in the essay, light gradually appears, accompanied by increased life courage.
\end{abstract}

\section{Keyword/Nøkkelord}

life courage; vital urge; nature; narratives; phenomenology

livsmot; natur; fortellinger; fenomenologi; livsfilosofi

\section{Referee*}


Här är en sång till

modet

Den är till alla dom

som vågar tro på

morgondan

fast natten är så lång

Här är en sång til

modet

en liten, enkel låt...

Sykepleiere, prester og leger møter ofte mennesker som er i vanskelige livssituasjoner hvor livsmotet er truet. Det kan beskrives forskjellig: å bli rystet, å stå på siden av seg selv, livet er på vent, å være kommet til et vendepunkt, livsveien kan synes uklar. A trenge støtte, noen ganger en varsom hånd, andre ganger et rekkverk til å holde seg fast i. Vi trenger alle mot for å fortsette videre fra tid til annen..

Dette essayet er et forsøk på å langsomt kretse inn ulike sider ved det vi kaller livsmot og ulike veier dit. Teologen Gustaf Wingren skriver:

"Termen "livsmod" är vag och därför i sammanhanget förträfflig. Den storhet som skall betecknas med termen, är nämligen variabel och skiftande från tid till tid under en människas levnad. Vad som håller samman de växlande formerna av livsmod är detta enkla, att de för individen gör det möjligt att oförfärat gå in i den nya dag som ligger framför honom (...)" (1995:135).

At begrepet livsmot av Wingren oppfattes som vagt, kaller på våre erfaringer for å tydeliggjøre og gripe flere sider ved fenomenet. Vaghet kan gi rom for forskjellighet. Noe kan være det samme, men samtidig ikke det samme. Vagheten kan også innebære en tilbakeholdenhet, en ydmykhet i forhold til livets omstendigheter. Det er ikke alt som kan eller skal gripes eller begripes. Ordet erfaring kommer av "å reise gjennom og å få tak i" (Caprona, 2013:933). Essayets veier går ikke alltid rett frem mot et mål, men søker seg frem langs mange omveier. "Vona er at framgangsmåten, altså vandringa om omvegen, i seg sjølv er med på å frambringe innsikt som elles ikkje ville kome til " (Nicolaysen, 1997:17). Essayet vil derved være en ytre, men også en indre vandring gjennom erfaring, kunst og poesi som forhåpentligvis kan vekke gjenkjennelse og undring hos leseren. Fortellingene vil fremstå som mosaikker, hvor skriverens mening noen ganger tones ned slik at leseren kanskje kan inspireres til selv å tenke videre. Hensikten er ikke å finne definisjoner, tiltak eller råd til helsepersonell, men en langsom tilnærming for om mulig avdekke

\footnotetext{
1 Tittelen er inspirert av Mikael Wiehes "En sång till modet". Sangen fikk en særlig betydning for mange under minneseremonien etter massakren på Utøya.
} 
nye og andre sider ved fenomenet. Fotnotene til denne teksten er ytterligere omveier og hvileplasser for spesielt interesserte og ikke på noen måte nødvendig for at leseren skal ha et utbytte av turen. Med på vandringen er livsfilosofiske følgesvenner og med tenkere som Knud Hansen, Knud E. Løgstrup, Mogens Pahuus og tradisjonen rundt dem.

Livsmotet kan ofte bli tydeligere når det er utfordret og kanskje oppleves som fraværende. Andre ganger legger vi ikke merke til det, selv om det bærer oss. Da er det en livgivende kraft som gir oss krefter og energi. Det er som vi tar livsmotet for gitt. Slik sett kan vi betrakte livsmotet som et usynlighets-fenomen. Det er som den blindes stav som opptrer som en forlengelse av kroppen. Livsmotet gir oss kraft og vitalitet til å møte verden. Først når staven skades eller knekker blir vi oppmerksom på dens funksjon. I grensesituasjoner hvor livet er på vippen, kan betydningen av livsmot bli mer fremtredende.

I essayet vil vi først starte med en pleiesituasjon hvor livsmotet er vaklende. Så vil vi begynne omveien ved å dvele over livsmotets tilsynelatende fravær, i det ytterste mørket. Senere i essayet vil lyset langsomt bli mer og mer synlig, og derved også livsmotet. Det tydeliggjør også at vi er hverandres verden og hverandres skjebne som Løgstrup utrykker det (1956:25-26). Å være menneske innebærer en gjensidig avhengighet. Det vi gjør eller ikke gjør påvirker andres liv. Det er så fundamentalt i livet at vi lett kan komme til å overse det.

\section{Med ansiktet vendt mot lyset}

Plantene i vinduskarmen min snur seg i retning av lyset, mot det som gir liv. Sykepleiepioneren Florence Nightingale beskriver for over 150 år siden hvordan pasienter gjør det samme (1997:128). Det er som de lengter etter det som kan gjøre livet godt. Det kan gi øyeblikk av lindring. Vi vet ikke alltid hva som bærer oss. Små øyeblikk kan bli store øyeblikk. Skjellsettende øyeblikk som vi har med oss i lang tid. Sykepleie finner sitt utrykk gjennom gjerningene. Det er det vi gjør og ikke gjør som får betydning. Det «gripes inn i» den andres liv.

Jeg blir bedt om å hjelpe til inne hos "Peter". Han er sengeliggende og har vart det $i$ mange måneder. Vi skal legge under et rent laken, han har store smerter så vi arbeider rolig og varsomt og bruker god tid. Mens vi holder på og han klager seg over smertene oppdager jeg fullmånen der ute i mørket. Den er stor og vakker og mørketiden er så vidt begynt. "Ser du månen?" spфr jeg "nei" sier han. Vi flytter litt på sengen og slukker lyset. "Å så vakker", sier han. Vi lar han ligge slik en liten stund, å se ut av vinduet, på månen og på stjernene. Det ble et pusterom for oss alle, en liten pause i det smertefulle. Vi hadde et фyeblikk av stillhet sammen, der vi så på månen. Vi gjør oss ferdig med lakenet og $i$ det vi 
skal forlate rommet, takker han oss. "Tusen takk for at dere tar dere tid."2 Veien fra sengen til stolen kan være lang. Noen ganger så lang at den kan være vanskelig å klare alene. Mye står på spill for denne pasienten. Om han ikke kommer seg opp, vil han ikke klare å bryte den innesperringen som lidelsen og sengen gir. Da står pasienten i fare for å dø litt etter litt. Sykepleierne våger å la evnen til følsom innlevelse og faglighet gi innsikt i noe av det som trengs $\mathrm{i}$ øyeblikket. De gripes av situasjonen og blir medvandrere som kan gå deler av veien sammen med pasienten. Han blir ved-rørende, én som angår oss, vår neste.

Den lille pausen og synet av månen kan kanskje bringe tilbake tidligere øyeblikk som forteller noe om hvem han er og hva som har gitt mot og glede. Pausen kan minne ham om det som har vært og det som fremdeles kan være der. Noen mennesker står i fare for å avslutte sin livsfortelling for tidlig (Binder, 2018:322). Håpet svekkes og de står i fare for å gi opp. Månen reflekterer solen og står som et lys i mørket. Den kan kanskje minne oss på opplevelser hvor vi har følt oss hjemme i verden og at noe kan være større enn oss. Sånn sett er det aldri helt mørkt selv om det i øyeblikket kan kjennes slik. Skygger fremkommer ved at noe lyser. Kari Martinsen (2018:9), skriver inspirert av Henrik Wivel:

"Men der livet kaster skygger, bæres det av lyset av en livskraft vi ikke har makt over, men som om og om igjen bryter gjennom, så det underfulle i livet, kan merkes, sanses, erfares. Vi holdes oppe og bæres av det hellige. Også i sykeværelset med alle dens ulike skygger."

En måte å forstå livsmot kan være det livgivende. Det som gir lys i tilværelsen og kraft til å fortsette.

La oss så forlate pleiesituasjonen og gå videre inn i opplevelsen av at skyggene går over i det fullstendige mørke.

\section{Om å komme i veien}

I Fjodor Dostojevskijs novelle «Et latterlig menneskes drøm» ${ }^{3}$ (1877) beskrives et menneske som litt etter litt oppfatter seg som latterlig og betydningsløs, til slutt dominerer det hans syn på seg selv. Men så går opplevelsen av å være latterlig over $\mathrm{i}$ en følelse av at ingenting lenger eksisterer, livet er uten sammenheng. Likegyldigheten har tatt over, livet er tomt og meningsløst. Han blir overbevist om at slik vil det fortsette å være i framtiden også. Mennesker slutter å gjøre inntrykk på ham. Skyggene har tatt over, livet oppleves som bare mørkt. Innesperret, som i en tunnel av likegyldighet bestemmer han seg for å ta

\footnotetext{
${ }^{2}$ Personlig anonymisert meddelelse

${ }^{3}$ Jeg forholder meg i denne sammenhengen kun til den første delen av fortellingen. Se f. eks. Knud Hansens bok Dostojevskij (1991 s.187 til 198) for en gjennomgang av hele novellen.
} 
sitt eget liv. Men da han har bestemt seg for å skyte seg så kommer det noen i veien:

"Og da, nettopp som jeg stod og så inn i himmelen, ble jeg plutselig grepet om albuen av denne lille piken. Gaten var allerede tom, det var nesten ikke et menneske å se. Langt borte i det fjerne satt en drosjekusk og døste på bukken. Piken var i åtteårsalderen, hun var kledd i en tynn kjole og hadde et tørkle om hodet. Helt gjennomvåt var hun, men det var særlig de våte hullete skoene jeg la merke til, dem husker jeg ennå. Hun grep meg plutselig om albuen og ropte et eller annet til meg. Hun gråt ikke, men stammet fram noen usammenhengende ord som hun ikke greide å uttale fordi hun frøs så hun skalv over hele kroppen. Hun var redselslagen og skrek fortvilet i ett sett: "mamma! mamma!" Jeg kastet et flyktig blikk på henne og gikk videre uten et ord, men hun løp bare etter meg og fortsatte å trekke meg i ermet, og i stemmen hennes lød nå den dypeste fortvilelse. Selv om hun ikke fikk sagt det hun ville, forstod jeg at moren hennes lå for døden et eller annet sted, eller at det var skjedd et eller annet forferdelig hjemme hos dem, og at hun hadde styrtet ut på gaten for å tilkalle hjelp, for å finne en eller annen som kunne hjelpe moren. Men jeg ble ikke med henne, jeg ville tvert imot jage henne bort. Først sa jeg at hun måtte finne en konstabel. Men da foldet hun plutselig de små hendene sine og løp ved siden av meg mens hun hulket og snappet etter pusten; det var tydelig at hun var redd for å forlate meg. Og da var det at jeg plutselig trampet med foten og ropte et eller annet til henne. Hun ropte bare: herre, gode herre! ..." Så løp hun plutselig over til den andre siden av gaten: der var det også en skikkelse som hastet avsted - hun styrtet fra meg over til ham" (s:155).

Fortelleren i historien blir bokstavelig talt «grepet» av den lille piken som tar tak i ham. Men han lar seg ikke gripe, hun angår ikke ham. Han ber henne finne en konstabel, med andre ord en som har det som sitt arbeid å ordne opp. Da det ikke nytter blir hun brutalt avvist. Der og da når hun ikke gjennom til ham. Men hendelsen har forstyrret ham i det han skulle gjøre, irritert vender han om og går hjem igjen. Allerede i irritasjonen har likegyldigheten begynt å krakelere. I irritasjonen er det noe som gjør inntrykk, uten at vi helt vil ta det innover oss. Det blir bare plagsomt.

Senere på kvelden innhentes han av det som skjedde. Den lille fortvilte jenten har likevel gjort inntrykk på ham. Når han sitter der i værelset sitt uroes han og undrer seg over at han faktisk synes synd på henne. Han våger å la seg ryste. og kjenner en smerte i møtet med henne, likegyldigheten har slått sprekker. Piken blir avvist, men setter spor i ham, han blir «grepet» av henne på flere måter. I ettertenksomhetens rom endrer livet retning. Det som først ble opplevd som en irriterende forstyrrelse blir et vendepunkt. Noe trenger seg gjennom og forbi likegyldigheten. Alt er ikke like gyldig. Livet er noe mer. En «merhet» som inne- 
bærer at vi står i noen sammenhenger som ikke er til å komme forbi. Vi er innvevd i hverandres liv. Denne merhethen er det lett å overse i det daglige.

Han føler skam over å ha avist henne, han burde ha handlet annerledes. Det er som det vokser fram et bør av livet selv. Gjennom å føle smerte for andre får han selv betydning som menneske." Følgende stod klart for meg: hvis jeg fremdeles er et menneske og ennå ikke et null, da lever jeg og kan fortsatt føle både vrede og smerte, føle skam over mine handlinger (...) " (157). I ettertanken rystes han av sin egen sårbarhet. Skam i en slik sammenheng blir som en moralsk rettesnor. Å våge å la seg gripe av andre blir viktig. Noe må få gjøre inntrykk på oss. Det vi gjør og ikke gjør har betydning utover oss selv i et mellommenneskelig fellesskap og den verden vi er innvevd i.

Personen i novellen har prøvd å bryte ut av livets sammenhenger. Likegyldigheten og tristheten har tatt over. Det er som om ingenting betyr noe, men den lille piken trenger likevel igjennom. Hun kommer i veien. Et lite фyeblikk er det som den lille piken uten å vite det bærer ham, i sin fortvilelse ryster hun ham, «langsomt får livet igjen mening». Han er ikke latterlig eller betydningsløs lenger, andre eksisterer og trenger ham. Han er fanget i likegyldigheten, men oppdager gjennom møtet med den lille piken at han ikke er en fortapt skipbrudden som driver rundt på meningsløshetens hav. Hans livsoppfatning vender om. Han kan bety noe for noen. Den lille piken angår ham. «Livsmotet får igjen rom til å vokse frem. Han kan igjen bli hjemme i verden.» Vi har alle ansvar for hverandre, noe som kan gi livet ny mening og form. Andre angår meg enten jeg vil det eller ikke. ${ }^{4}$

Det er to lidende mennesker som møtes i Dostojevskijs novelle. For begge befinner livet seg i en vippeposisjon hvor utfallet kan bli forskjellig. Den lille piken skumper borti personen og får livet hans til å endre retning. Før det har han tilsynelatende ingenting å bære, kun det som oppleves som likegyldighet. Men han bærer på noe mer, sin egen lidelse. Det kan være tungt, så tungt at livet ikke er til å holde ut.

Piken får ikke hjelp og møter hans brutale avvisning. Bevegelsen blir dobbel og går i ulike retninger. Novellen kretser rundt valg og etiske grunnfenomener. Likegyldigheten utfordres i forhold til barmhjertighet og livsmot. Skammen vokser frem som en etisk størrelse. Burde jeg ikke ...

Fortellingen kan minne om fortellingen om den barmhjertige samaritan, men resultatet er annerledes. Liknende grunnfortellinger der barmhjertigheten ikke

\footnotetext{
${ }^{4}$ Jeg er senere blitt klar over at Johannes Møllehave omtaler novellen i boken Til glaedens Gud (1977) der skriver han et brev til Edit Södergran etter hennes selvmordsforsøk. Han skriver om novellen: "Det er Dostojevskijs påstand at ingen ejer livet i sig selv, at det først vågner til live i et menneske, når det vækkes til live af den virkelighed man har omkring sig (...)" (87).
} 
når igjennom, finnes det mange av i litteraturen (se Thorsen, 2012:18-22). Mannen i Dostojevskijs novelle velger også å gå forbi, men livet innhenter ham og forandrer ham i ettertid. Vi trenger slike grunnfortellinger, også fortellinger om når vi ikke møter appellen fra andre. De etiske grunnfortellinger forteller om noe som står på vippepunktet, utfallet kan bli forskjellig. I lidelsen står livsmotet på spill. Vi er ikke alene på livets vei, selv om det noen ganger kan føles slik. Det vi gjør og ikke gjør har betydning for de omgivelsene vi alle er en del av. Uten at vi alltid tenker over det skumper vi borti hverandre på godt og vondt. Våre liv er alltid sammenvevd i gjensidig avhengighet. I vår rettethet mot andre kan det åpnes opp for muligheter. Det er i «møte med andre», personen i novellen kan finne mening og livsmot. Vår gjensidige avhengighet (Inter dependens) er så sentral i våre liv at den lett kan oversees og glemmes. Dette er vesentlig både i Dostojevskijs og Løgstrups forfatterskap.

\section{Mørket}

Når jeg skriver dette strømmer refrenget til Einar Roses gamle revyvise ${ }^{5}$, ut av radioen: «Sol ute, sol inne».

Visen vekker en motstand i meg. Munterheten kan for noen oppleves som et disharmonisk skrik. Tonen vekker ingen god gjenklang. Tristheten kan være for stor. Noen ganger oppleves livet som uendelig tungt. Det er ikke alltid mennesker klarer å se eller å kjenne på solens og lysets tilstedeværelse. En kan føle seg hjemløs. Var det slik personen i Dostojevskijs novelle opplevde det?

Natten senker seg, kreftene tar slutt, verden blir ufrivillig langsom, for til slutt å etterlate mennesket i en fortvilet følelse av at alt går i stå. En er innesperret, ingenting nytter. Det tunge mismotet og håpløsheten får råde grunnen alene. Livsmotet kan synes helt lammet eller borte, livet er ikke lenger livet verdt ... en tilstand legevitenskapen beskriver som en depresjon. Når livet oppleves som svart og dagene er tunge kan andres munterhet være vanskelig, for ikke å si umulig å møte. Kroppen nedsenkes i en mørk dvaleliknende tilstand, en makter ikke med livet. En er ytterst alene og fortapt i det beksvarte mørket. "Du faller vekk fra sollyset til et sted fullt av svart skygge"(Solomon, 2003:27).

Ropet om at vår tilværelse skal mestres kan virke sårt og meningsløst om det $\mathrm{i}$ det hele tatt når inn til den som lider.

Samtidig kan det noen ganger dypt inni mørket oppstå en lengsel etter lyset. Langt inne kan det være et ønske om noe annet. Men smerten i bunnen av viljen kan være for stor og overveldende. Noen ganger kan tiden og naturen hjelpe, andre ganger må det et medmenneske til. Når vi ikke selv makter å se lyset så

\footnotetext{
${ }^{5}$ Einar Rose (1898-1979) fremtredende revypersonlighet. Refrenget lyder Sol ute, Sol inne/Sol i hjertet, sol i sinnet/Sol bare sol
} 
trenger vi hjelp, for at lammelsen skal gi slipp. Vi trenger igjen å få kontakt med livsmotet som kan være der et sted langt inne. Andres ekte nærvær kan kanskje bidra til en liten sprekk hvor lyset uendelig langsomt på nytt kan trenge inn og skimtes. Noen ganger trenger vi sårt at noen kommer i veien. I depresjonen kan livsmotet være lammet (Jensen, 2012).

Det er ikke alle som møter depresjonens mørke på livets vei. Men like så sikkert som det er at vi er født inn i denne verden, er det at vi en gang skal forlate den. Sorgens mørke er en nødvendig følge av kjærligheten. Vi mister de vi er glad i. Det som bidrar til å opprettholde vårt livsmot er så selvfølgelig at vi tar det for gitt, kun når det er borte ser vi det. Det som bar oss er borte, fotfestet glipper. Mange opplever å stå utenfor seg selv, å samle seg igjen kan ta tid. Skygger kan noen ganger gi oss nødvendig ly når livet blir vanskelig. Sorgen må ta den tiden den trenger uten at mørket skal defineres inn i kategorier og faser. Sorgen og mørket kan kanskje hjelpe oss til å langsomt se hva som har virkelig verdi i livet og som det går an å gjenfinne livsmotet med. Det som bærer oss ser vi først når vi er i ferd med å miste det. Perspektivet kan endre seg. Mørket kan i ettertid gi livet ny fylde.

\section{Følge på veien}

Mennesket har mulighet til å ødelegge og å sperre inne. Vi er sårbare og avhengige av den verden og historien vi er en del av, noe er større enn oss. Livet utfolder seg mellom skapelse og tilintetgjørelse (Løgstrup, 1978). Krig er menneskeutløst destruktiv ødeleggelse som ofte rammer uskyldige sivile; kvinner, eldre og barn. Den kjente amerikanske fotoessayisten W. Eugene Smith skulle dokumentere krigshandlinger under andre verdenskrig. Bildene hans endret seg fra å være bilder som kunne brukes til å hylle krigshelter til gripende dokumentering av krigens ødeleggelser og redsler. Han ble såret og måtte gjennomgå en rekke operasjoner og en smertefull langvarig rehabilitering. Sykepleiere og leger har vært der for ham. Det første bildet han tar etter to års lidelse blir ikonisk. I et essay i boken «Art \& Artist» (1956) beskriver han omstendighetene rundt tilblivelsen av fotografiet. En dag når han er alene med sine to minste barn får han en intens lyst til å prøve å fotografere igjen. Fotografi er slik han ser det en viktig del av det han er og gjør. Han står i fare for å miste en helt vesentlig del av sin evne til å utrykke seg. En kunstner uten sitt "medium" er en fortapt sjel. Mye står på spill, noe som får han til å forstå uten noen sammenlikning forøvrig hvordan Beethoven kunne ha opplevd det når han langsomt ble døv. Etter at Eugene Smith har strevet lenge med å sette film i kameraet, tar han med de to små ungene ut på tur. Ungene utforsker skogen, en ny og spennende verden, mens han prøver å finne tilbake til evnene og ferdighetene han hadde før han ble såret. Skadene han har er store, det er vanskelig å få kroppen til å fungere. Kroppen er blitt fremmed, det er som et brudd med hans tidligere tilværelse. Det som før for ham var en instinktiv 
automatisert prosess går nå langsomt og vaklende. Han må finne tilbake til seg selv både fysisk og mentalt. Puss og sårvæske drypper på fotoapparatet og gjør det problematisk å se gjennom linsen. Det er vanskelig å fokusere korrekt. Han går der, litt bak ungene og prøver gang på gang å tenke gjennom hva han skal gjøre, repetere bevegelsene og få kroppen til å fungere sammen med kamera. Han må ikke bare få til bevegelsene, men samtidig håndtere sin egen indre uro. Ungene enser ikke hva han holder på med, de småprater henrykt om det de oppdager og løper rundt på både på og utenfor stiene i vegetasjonen under de høye trærne. Hver gang de oppdager noe nytt roper de til hverandre og tar hverandre i hendene for å vise hverandre det de har oppdaget. Det er som om han og barna er i forskjellige verdener, den samme og ikke den samme. Han fikk tatt bildet som senere får tittelen «Walk to Paradise Garden» (en vandring til paradisets hage $)^{6}$. For barna et henrykt livsmot, en lykkelig selvforglemmende lek og utforsking av en spennende verden. For ham er det en opplevelse av å makte å finne tilbake til seg selv, å overskride bruddet som har vært i tilværelsen, livsmotet kan igjen få rom. Han ser ungenes glede og kan ta del i den, de blir drivkrefter som får ham til å holde ut. Eugene Smith beskriver det: «Når jeg fulgte etter ungene i undervegetasjonen og mellom de store trærne var oppdagelsesgleden deres allestedsnærværende. Når jeg så på dem visste jeg at på tross av alle kriger og alle tilbakeslag at jeg i dag, akkurat der og da ønsket å synge en sang til livet og ønsket om å fortsette å leve» $(1956: 216)^{7}$. Det ser ut til at livsmotet på ny har funnet en grobunn og kan fortsette å vokse. Han er i ferd med å finne tilbake, og på nytt bli hjemme i seg selv. Igjen ser vi hvordan barn kan gripe inn i vår tilværelse og gi den form. Vi påvirker hverandre. Gjennom barna finner han tilbake til seg selv. Bildet ${ }^{8}$ viser de to barna fotografert bakfra. Gutten går først og holder den lille jenta som går litt bak ham i hånden. Lyset gjør at han blir mørk mens den lille jenten blir lysere. Han holder hodet slik at det ser ut som han ser noe fremfor seg som han vil vise henne. De kommer fra den mørke skogen og vandrer inn i lyset. Skogen omhyller dem og lyset gjør skogen svakt hjerteformet. Bildet kan kanskje også sees på som en vandring langs livsveien, her finnes både tillit, åpenhet for verden, livsglede og livsmot. Mørke blir til lys.

\footnotetext{
${ }^{6}$ Bildet har fått navn etter et av Eugene Smiths favoritt musikkstykker av Frederick Delius. Musikken kan gi et kunstnerisk innblikk i stemningen i bildet (Stephenson, 2001). Det antyder også hvordan musikk kan bidra til at en kan finne tilbake til seg selv og at livsmotet på nytt kan få rom.

${ }^{7}$ Min oversetting, opprinnelig sitat: "And, as I followed my children through the underbrush and the tall trees - what joy of discovery was everywhere theirs - and as I watched I knew again that in spite of all of it, and in spite of every war, and of every setback, that today, now. I wanted to sing a sonnet to life and of the worth of continuing, and in living it " (216) (min utheving).

${ }^{8}$ https://time.com/37534/into-the-light-w-eugene-smiths-walk-to-paradise-garden/
} 
Fotografiet kan minne om et norsk kunstverk «Fylgje» av Kaare Espolin Johnson. ${ }^{9}$ Det viser to små gutter på vandring over myrene gjennom natten. Den lille månesigden lyser på dem bakfra. Den fremste skikkelsen er mørk, den andre lys. Det ser ut som de holder hender, selv om hendene ikke er synlig. Den lyse gutteskikkelsen har lukkete øyne. Han har hånden i lommen og kan ikke engang ta seg for om han faller. De er «hjemme i opplevelsen og landskapet». Det er som bildet utstråler en tillit imellom dem der de vandrer gjennom natten. Det er som om det lille følget er hjemme i seg selv og landskapet. Kanskje er det livsmotet som trer frem i to bildene. "Espolin beskriver bildet som et minne om en ekspedisjon han og en kamerat hadde over russegrensen i Pasvik. Men han beskriver også en tydningsdimensjon i dette: "Jeg tenkte også på den vakre, gamle tro at hvert menneske har et godt fylgje, derfor laget jeg den ene gutten lys - med drømmen i seg "" (sitert i Norderval, 2007:141). Fylgje kommer fra norrøn mytologi og er en kvinnelig verneånd/skytsånd. Ifølge folketroen er det et vesen som følger et menneske (Caprona, 2013:866). De to kunstverkene har noe til felles, en åpenhet til verden som vi er en del av. Den lyse gutten vandrer med tilsynelatende lukkede øyne, en hånd i lommen og hånd $\mathrm{i}$ hånd med den andre. I Eugene Smiths fotografi er det den lille jenten lyset faller på, der hun hånd i hånd følger etter gutten. Eventuelle farer rundt dem ser ikke ut til å eksistere. Det er som om de vandrer omhyllet av åpenhet og tillit. Barns åpenhet mot verden er naturlig om den ikke møter hindringer ${ }^{10}$. I bildet fra begge kunstnerne er naturen vesentlig, begivenhetene «finner sted» der. Naturen er ingen kulisse, men en viktig del av bildene. I Eugene Smiths bilde omslutter naturen de to barna, trærne danner et hjerte rundt dem. De vandrer ikke kun som tilskuere i naturen, men som deler av den. Stedet stemmer sinnet. Naturen utgjør en underst $\varnothing t t e l s e ~ o g$ forutsetning for livsmotets fremvekst. I vår avhengighet er vi uløselig knyttet til naturen, som forutsetning for alt liv.

\section{Mellom skapelse og tilintetgjørelse}

Livsmot må ikke bare forstås $\mathrm{i}$ et her og nå perspektiv, men også ut over vår levetid. Den nåværende verdensituasjonen med global oppvarming gjør det

\footnotetext{
${ }^{9}$ Fotografen Rune Johansen beskriver i en samtale med kunsthistorikeren Aaslaug Vaa (2007 s.176), hvordan dette bildet minner om et norsk kunstverk: Fylgje av Kaare Espolin Johnson. Bildet ble først trykket i 1949 som en illustrasjon til fortellingen Jul-fremmede, altså noen år etter Eugene Smiths fotografi. Navnet Fylgje fikk kunstverket først i 1958 da det ble brukt som utsmykning på hurtigruteskipet Harald Jarl. Bildet henger nå på hurtigruteskipet Trollfjord. https://www.dagensperspektiv.no/2010/vaeret-arbeidet-og-slitet

${ }^{10}$ Armgard viser til Løgstrups kommentar til den etiske fordring (1961:220) og skriver: "Barnets absoluta avhängighet av föräldrar och av andra människor avspeglas på et naket sätt $i$ dess omedelbara tillit till att dessa är inställda på och även i stånd att ge barnet, vad det behöver. Denna grundtrygghet $i$ en öppen och försvarslös attityd gentemot omgivningen är också nödvändig för barnets psykiska hälsa. Utan denna kommer barnet liksom senare den vuxne att sakna den nödvändiga grundvalen för sitt livsmod" (1971:132) (min utheving).
} 
tydeligere at vi også holder noe av livsmotet til fremtidens barn i våre hender, deres handlingsrom kan stå i fare for å bli mindre. Vi er alle globale medvandrere. Om vi våger å tenke videre kan vi se at våre gjerninger kan få myrene til å ødelegges og isen til å smelte. Guttenes vandring kunne i en fremtid blitt enda mer farefull. Jan-Magnus Bruheim ${ }^{11}$ har et dikt med tilsvarende tittel som Espolin Johnsons kunstverk. Her er diktet «Fylgje» fra diktsamlingen «Kan eg nå di hand $(1984$, s. 89):

«Frå fyrste dagen var det to som fylgde ved din side Den eine var ditt unge mod, den andre var din kvide

Ei glede drog i handi di dei ljose lukkestunder Men sorgi kom med handi si og let ein verd gå under.

To fylgjer deg. Den fyrste dag da du tok til å vandre greip livet kring di eine hand og døden kring den andre.»

Bruheim setter ord på våre naturlige livsbetingelser. Livet utfolder seg mellom fødsel og død. Mellom lys og mørke. Det er som er vi innvevd i og derved en del av en pågående skapelse. Noen vil muligens heller bruke ordet tilblivelse. Livet vokser frem, visner og vokser frem igjen. I livet følger livets tilintetgjørelsesprosesser som en naturlig konsekvens. Slekt følger slekters gang. Naturen er en nådegave som gir muligheter for vekst, men nedbrytningen $\mathrm{i}$ naturen er også en forutsetning for at nytt liv skal kunne vokse frem. Både vekst, lidelse og død blir en naturlig del av livet. Mennesket er ikke utenfor naturen, vi er "med åndedræt og stofskifte indlagte i naturens kredsløb" (Løgstrup, 1984:11). Alt liv er liv i avhengighet. Det er rammene som omslutter oss. Det vi gjør og ikke gjør påvirker naturen som vi er innfelt i. Ved disse livsbetingelsene følger det også at vi har et ansvar for hverandre også ut over vår egen levetid. Lidelsen og tilintetgjørelsen hører livet til, det er ikke til å komme utenom. Det vil alltid oppstå bruddflater. Det er i dette mellomrommet mellom skapelse og tilintetgjørelse, lidelse og livsmot at sykepleien har sitt arbeidsfelt. Ikke kun som spontane menneskelige handlinger, men også som faglig begrunnet kunnskap. Kari Martinsen skriver i forordet til «Den omtenksomme sykepleier» (1993): "Lidelse forutsetter livsmot. Det er i spenningen mellom lidelse og livsmot - slik vi møter dette hos den som trenger hjelp - at helseprofesjonene har utviklet sin

\footnotetext{
${ }^{11}$ Tillatelse til bruk av diktet er innhentet fra Torunn Bruheim Haugen
} 
fagidentitet. Vi må både kunne se og utrykke appellen om hjelp for å kunne styrke livsmotet i lidelsen. Medfølelse, barmhjertighet, tillit og ærlighet arbeider sammen med fagkunnskap når vi handler riktig og godt mot andre" (9).

\section{Den lille gutten, leken og trehjulssykkelen}

"Trine", er sykkelen her enda? Jeg nikker, med et stort smil hiver han seg på trehjulssykkelen og suser nedover korridoren på barneavdelingen.

Det har ikke alltid vart slik, nå er han tilbake til kontroll. For mange uker siden var han en liten redd og angstfylt gutt. Før han kom til oss hadde han vart på et lite lokalsykehus. Der ble han innlagt med en alvorlig sykdom og trengte antibiotikabehandling. Legene hadde ikke fått til å legge inn et venekateter, derfor hadde han fått injeksjoner med antibiotika flere ganger daglig. Da de gjorde det ble han holdt fast. Smertefullt på mer enn en måte, det satte spor. Noe av tilliten ble фdelagt. Da han ble overført til barneavdelingen fikk han antibiotika intraven $\phi s t$. Første gangen jeg skulle skifte på bandasjen hans brukte jeg hele vakten på å få han til å stole på meg. Vi lekte lenge med småbiler og tegnet. Så våget han å vise meg bandasjen etterfulgt av mer leking. Vi pratet lenge om han skulle tegne på den. Når vi var ferdig tegnet han et stort smilemerke med tusj på bandasjen, etterpå var det hjemmespill og latter. Det var en stolt gutt som senere viste fram smilemerket til foreldrene.

Det er lenge siden guttens innleggelse. Men jeg er fremdeles grepet av opplevelsen. Det gjorde inntrykk på meg. Det var en slags resonans i situasjonen. Slik kan det nok være for gutten også. Det er som om kroppen husker, mange år etterpå kan vi bli innhentet av det vi sto i. I dag ville nok behandlingen vært annerledes. Den var kanskje livreddende, men injeksjonene og tvangen gjorde at han ble revet ut av sine sammenhenger. Angsten og redselen var en naturlig følge av det. Samtidig ble situasjonen enda mer forverret ved at foreldrene dessverre ikke hadde mulighet til å være hos han hele tiden. Den selvforglemmende leken ble en vei tilbake til tryggheten og den han var. Pahuus (2019) beskriver hvordan lek ytrer seg hos barn og kan være opphav til livsmot. Leken kunne hjelpe gutten til å igjen føle seg hjemme i sin verden.

\section{Fortrolighet med verden, trådene samles}

Martin Heidegger beskriver en tilværelse hvor en er kastet inn i verden, samtidig som fortroligheten med verden er brutt sammen. I angsten er det uhyggelig (unheimlich), en tvinges i hjemløshet. En hører ikke lenger til (das Nichtzuhause-sein) (Væren og Tid, 2007:180). Slik var det kanskje for mange av dem det fortelles om i dette essayet. Sykdom og skader hadde gjort at det hjemlige i deres tilværelse brøt sammen. Det er mulig å tenke seg livsmot som en tilstand, 
hvor en opplever seg som «hjemme i verden» og seg selv (i egen kropp) ${ }^{12}$. En tilstand av å føle at en hører til, er innvevd i en sammenheng. En sammenheng hvor en føler seg opplivet og har håp. Hvordan dette viser seg vil variere fra menneske til menneske og gjennom livsløpet. Noen sider ved livsmotet kan oppstå tidlig i livet. Da som en mer opprinnelig stemthet enn angst som Heidegger beskriver (Pahuus, 1986:129). Angt som en kastethet ut i verden opptrer senere. Det hele starter i vår grunnleggende avhengighet av relasjoner til andre, både til mennesker og naturen som vi er en del av. De fleste av oss har eller har hatt relasjoner, steder og landskap vi føler oss «hjemme» i, hvor vi kunne puste fritt. For noen er det åpen natur, for andre et bylandskap. For andre igjen er det ønsket om å hvile i vårt eget lille lune rede, hvor verden føles oversiktlig og trygg. Nærhet til familie og venner. I sykdom og lidelse kan det oppstå brudd i tilværelsen, det som omgir oss bli knugende og holde oss fast i en innesperring. Fortroligheten med verden kan slå sprekker.

I den lille fortellingen «med ansiktet vent mot lyset» er Peter preget av smerter og ute av seg selv. Synet av den store månen gir ham et nødvendig pusterom og en vei tilbake til tidligere opplevelser. Et rom hvor han kanskje kan finne nye krefter til å holde ut. Men han er helt avhengig av den hjelpen sykepleierne kan gi. Vi kan trenge tid og forståelse for å finne tilbake til oss selv. Også i Dostojevskijs novelle beskrives et menneske som hjemløs. Fortelleren opplever tilværelsen som meningsløs og ønsker å forlate og bryte ut av verden. Den fortvilte lille piken holder ham tilbake og viser at livet igjen kan ha mening. Det er i sammenheng med andre han finner at han igjen har muligheter til å bli hjemme i seg selv. I sorgen kan tapet være så stort at vi står på siden av oss selv, alt er brutt sammen. Alt er på vippen, fotfestet er borte. I ve-mod, i minnene om de vi har mistet kan det langsomt få vokse fram nytt mot. Men det kan ta tid. I Eugene Smiths fortelling er kroppen skadet, det er som om bevegelses-mønstre og det som tidligere gikk uten at han trengte å tenke over det er blitt borte, kroppen er blitt fremmed. Den kroppslige fortroligheten kan være slik at vi først legger merke til den når den er truet. Det er også her skjedd et brudd i tilværelsen. Livet er blitt fragmentert, det er noe som ikke har funnet sin plass. Han må selv gjenfinne fortroligheten med kroppen og den han er. Han kjemper en kamp for å finne tilbake til seg selv, til det som ga ham selvfølelse og selvrespekt. På turen ut i skogen sammen med ungene begynner han å finne tilbake til seg selv, verden kan igjen bli rommelig. Han er på nytt hjemme i seg selv, i sin egen kropp og sine sammenhenger. Samtidig fortelles det to parallellen historier barna er i det selvforglemmende, oppslukt av sin lek. I deres situasjon er livsmot en livsbejaende kraft og vitalitet. Møte med mennesker som på ulike vis er blitt hjemløs i egen kropp er en vesentlig del av sykepleien (Balteskard, 2008; 2019).

\footnotetext{
${ }^{12}$ Hjemme brukes her annerledes enn det Hartmut Rosa gjør i sin diskusjon rundt resonans og hjemlighet (2019:359)
} 
Livsmotet utfordres i bruddflatene og kan føles vaklende eller fraværende. Da må sykepleieren noen ganger tre inn og understøtte pasienten om han ikke selv klarer å finne veien til nytt livsmot. I fortellingen om den lille gutten og trehjulsykkelen har han blitt så skremt av behandlingen han har vært utsatt for at noe av tilliten og fortroligheten til verden er brutt sammen. Sykepleieren hjelper han varsomt gjennom leken å finne tilbake til seg selv. Løgstrup (1956:37) skriver om å bryte den annens innesperring slik at blikket kan runde en vid horisont. Den andres verden må få bli så rommelig som mulig. Hvordan det skal gjøres sier ikke Løgstrup noe om. Han sier derimot: "Det hører fordringen til, at den enkelte selv med hvad han nu måtte have i behold af indsigt, fantasi og forståelse skal se at komme på det rene med, hvad den går du på (32)".

Noen ganger kan de små gjerningene bli kvist og blad som kan bidra til håpets og livsmotets bål. En varme som kan trenge gjennom lidelsens kulde. Da kan de små gjerningene bli store og viktige. Sykepleien kan bli et følge (Fylgje), en medvandrer et stykke på veien. Varsomt, faglig og oppmerksomt kan sykepleieren prøve å dempe lidelsen og understøtte livsmotet. En medvandrer kan noen ganger bidra til lysglimt som får livet til å endre retning eller bli lettere å bære. Mørke kan igjen bli lys.

I begynnelsen av essayet siterte jeg Wingren når han skriver om livsmot:"(...) Vad som håller samman de växlande formerna av livsmod är detta enkla, att de för individen gör det möjligt att oförfärat gå in i den nya dag som ligger framför honom (...) " (1975:135). Det er mulig at livsmotet starter som livskraft og vitalitet hos barn som ikke har ord, for så å langsomt vikles ut gjennom alle våre relasjoner i løpet av livet. At det utfordres og kan styrkes når tilværelsen brytes opp. Det er i disse bruddflatene livet finner «sted». Når vi utfordres, kan vi om vi er heldig finne nye veier for igjen å bli hjemme i oss selv. Men vi kan trenge hjelp på veien. Hvordan det kan skje vil variere fra menneske til menneske. Mosaikkene som er skissert i teksten, kan aldri bli helt ferdig. Livet pågår. Håpet er at tankene kan fortsette der teksten slutter.

Takk for følget

\section{Litteratur}

Armgard, L-O. (1971) Antropologi. Problem i K.E. Lögstrups författarskap. Köbenhavn: Gyldendal.

Balteskard, B. (2008) Hjem, tilhørighet og sted - den gamle, syke pasientens livsbetingelser. I: S. Hauge, F. F. Jacobsen (Red.), Hjem, eldre og hjemlighet, (s. 69- 86). Oslo: Cappelen.

Balteskard, B. (2019). Natur, fortelling og sykdomserfaringer - betydning for opplevelse av livsmot. Nordisk Tidsskrift for Helseforskning, 15(2), 12. https://doi.org/10.7557/14.4865 
Binder, P. (2018) Hvem er jeg. Om å finne og skape identitet. Bergen: Fagbokforlaget.

Bruheim, J-M. (1984). Kan eg nå di hand. Oslo: Aschehoug.

Caprona, Y.D. (2013). Norsk etymologisk ordbok. Oslo: Kagge.

Dostojevskij, F.M. (1877). Et latterlig menneskes drøm. I: En forfatters dagbok. (2.utg.1993). Oslo: Solum.

Eugene Smith, W. (1956). Walk to Paradise. In Art \& Artist. (s. 207-218). Berkeley and Los Angeles: University of California press.

Hansen, K. (1991). Dostojevskij. (2.utg). København: Gyldendal.

Heidegger, M. (2007). Varen og tid. Oslo: Bokklubbens kulturbibliotek.

Jensen, O. (2012). Livsmodet er lige så grundlaggende for livet som føden.

Kristeligt Dagblad. Hentet fra:

https://www.kristeligt-dagblad.dk/debat/livsmodet-er-lige-så-

grundlæggende-livet-som-føden

Løgstrup, K.E. (1956). Den etiske fordring. København: Gyldendal.

Løgstrup, K.E. (1978). Skabelse og tilintetgфrelse. Religionsfilosofiske betragtninger. (Metafysik IV). København: Gyldendal.

Løgstrup, K.E. (1984). Ophav og omgivelse. (Metafysik III). København: Gyldendal.

Martinsen, K. (1993). Den omtenksomme sykepleier. Oslo: Tano.

Martinsen, K. (2018). Bevegelig berørt. Bergen: Fagbokforlaget.

Møllehave, J. (1977). Til gladens Gud. Pradikener og andet. Aalborg: Lindhardt og Ringhof.

Nicolaysen, B.K. (1997). Omvegar fører lengst: stykkevise essay om forståing. Oslo: Samlaget.

Nightingale, F. (1997). Notater om sykepleie. Samlede utgaver. Oslo: Universitetsforlaget.

Norderval, Ø. (2007). Utlevert til livet. Espolin Johnson i et teologisk perspektiv. I: Aa. Vaa (Red.) ^ låne фyne å se med. Kaare Espolin Johnsons kunstnerskap. Trondheim/Kabelvåg: Tapir.

Pahuus, M. (1986). Livsfilosofi. Lykke og lidelse i eksistens og litteratur. Århus: Philosophia.

Pahuus, M. (2019). Livsmod. Nordisk Tidsskrift for Helseforskning, 15(2), 21. https://doi.org/10.7557/14.4908

Rosa, H. (2019). Resonance. A Sociology of Our Realationship to the World. Medford: Polity.

Solomon, A.(2003). Mørke midt på dagen, en bok om depresjon. Oslo: Gyldendal.

Stephenson, S. (2001). W. Eugene Smith 55. New York: Phaidon Press.

Thorsen, R. (2012). A skrive livet frem. I: R. Thorsen, K.S. Mæhre og K. Martinsen (Red.), Fortellinger om etikk. (s. 17-42). Bergen: Fagbokforlaget.

Vaa, Aa. (2007). Det hverdagslige, samtale med fotografen Rune Johansen. I: Aa. Vaa (Red.) Ålåne фyne å se med. Kaare Espolin Johnsons kunstnerskap. Trondheim/Kabelvåg: Tapir. 
Nordisk Tidsskrift for Helseforskning nr. 2-2019, 15. årgang

Wiehe, M. (2000) En sång till modet. (Spor 10). Fra: En sång till modet. Parlophone Music Sweden.

Wingren, G. (1995) Credo. (2.utg) Skellefteå: Artos. 